\title{
Poly(pyrazol-1-ylmethyl)benzene Palladium Complexes: Synthesis, Characterisation and Evaluation as Heck Coupling Catalysts
}

\author{
Nthabiseng M. Motsoane ${ }^{\mathrm{a}}$, Ilia A. Guzei ${ }^{\mathrm{b}}$, and James Darkwa ${ }^{\mathrm{a}}$ \\ a Department of Chemistry, University of Johannesburg, Auckland Park Kingsway Campus, \\ Auckland Park 2006, South Africa \\ $\mathrm{b}$ Department of Chemistry, University of Wisconsin-Madison, 1101 University Avenue, \\ Madison, WI 53706, USA
}

Reprint requests to Prof. Dr. J. Darkwa. E-mail: jdarkwa@uj.ac.za

Z. Naturforsch. 2007, 62b, 323-330; received November 18, 2006

Dedicated to Prof. Helgard G. Raubenheimer on the occasion of his $65^{\text {th }}$ birthday

\begin{abstract}
The poly(pyrazol-1-ylmethyl)benzenes $\mathbf{L 1}-\mathbf{L 5}$ react with $\left[\mathrm{PdCl}_{2}(\mathrm{NCMe})_{2}\right]$ or $[\mathrm{PdClMe}(\mathrm{COD})]$ to form dinuclear palladium complexes $\left[\left\{\mathrm{PdCl} X\left(3,5-\mathrm{Me}_{2} \mathrm{pzCH}_{2}\right)_{2}-1,2-\mathrm{C}_{6} \mathrm{H}_{4}\right\}_{2}\right](X=\mathrm{Cl}(\mathbf{1})$, $\mathrm{Me}(\mathbf{2})),\left[\left\{\mathrm{PdCl}_{2}\left(3,5-\mathrm{Me}_{2} \mathrm{pzCH}_{2}\right)_{2}-1,3-\mathrm{C}_{6} \mathrm{H}_{4}\right\}_{2}\right](\mathbf{3})$, palladium complexes $\left[\left\{\mathrm{Pd}_{2}(\mu-\mathrm{Cl})_{2} \mathrm{Me}_{2}(3,5-\right.\right.$ $\left.\left.\left.\mathrm{Me}_{2} \mathrm{pzCH}_{2}\right)_{2}-1,3-\mathrm{C}_{6} \mathrm{H}_{4}\right\}\right](4),\left[\left\{\mathrm{Pd}_{2}(\mu-\mathrm{Cl})_{2} X_{2}\left(3,5-\mathrm{Me}_{2} \mathrm{pzCH}_{2}\right)_{2}-1,4-\mathrm{C}_{6} \mathrm{H}_{4}\right\}\right](X=\mathrm{Cl}(\mathbf{5}), \mathrm{Me}(\mathbf{6}))$, $\left[\left\{\mathrm{Pd}_{2}(\mu-\mathrm{Cl})_{2} \mathrm{Cl}_{2}\left(3,5-{ }^{t} \mathrm{Bu}_{2} \mathrm{pzCH}_{2}\right)_{2}-1,4-\mathrm{C}_{6} \mathrm{H}_{4}\right\}\right](7)$, and tetranuclear $\left[\left\{\mathrm{Pd}_{2}(\mu-\mathrm{Cl})_{2} \mathrm{Cl}_{2}(3,5-\right.\right.$ $\left.\left.\left.\mathrm{Me}_{2} \mathrm{pzCH}_{2}\right)_{2}\right\}_{2}-1,4-\mathrm{C}_{6} \mathrm{H}_{4}\right](\mathbf{8})$. The structures of $\mathbf{1}, \mathbf{2}$ and $\mathbf{8}$ were confirmed by X-ray structure analysis. The complexes efficiently catalyse the coupling reaction of iodobenzene and butylacrylate at $80{ }^{\circ} \mathrm{C}$.
\end{abstract}

Key words: Poly(pyrazol-1-ylmethyl)benzene Ligands, Palladium Complexes, Crystal Structures, Heck Coupling, Catalysts

\section{Introduction}

The surge in research on nitrogen-based late transition metal complexes in the past twelve years or so has been spurred by the applications of these metal complexes mainly in catalysis [1]. Most of the work on catalysis has focused on olefin oligomerisation and polymerisation reactions, but of late there is an emergence of the use of nitrogen-based palladium complexes in Heck coupling reactions, viewed as alternative catalysts to the more expensive and sensitive phosphine-based palladium catalysts. Two types of nitrogen-based palladium Heck coupling catalysts are known. First is the group in which the nitrogen atoms in the ligand are bonded to the palladium. This includes the highly active bis(pyridine) palladium Heck coupling catalysts recently reported by Kawano et al. [2] and other nitrogen-donor ligand palladium catalysts [3]. The second type is represented by $N$ heterocyclic carbene complexes, popularised by the Herrmann [4] and the Cavell [5] groups, with no direct palladium-nitrogen bond. It is therefore not surprising that using a mixture of carbene and nitrogen-donor ligand types also produces active catalysts for Heck cou- pling reactions [6]. Some of the nitrogen-donors used are pyrazoles which are present in some of the very active non-phosphine palladium catalysts known [6b,c], but to date a ligand system containing only pyrazole is yet to be used to catalyse Heck coupling reactions.

Most of these ligands are either added to a palladium(II) salt or used as a preformed palladium complex of the ligand. A few examples where palladium is replaced with a cheaper metal are known. The most successful of these palladium replacement catalysts contain nickel, but even here activity is inferior to that of the analogous palladium catalysts [7]. In fact a recent theoretical study comparing nickel and palladium catalysed Heck coupling reactions could only conclude that nickel catalysts are promising with phosphine and pyridine as they are the only ligands that can reasonably reduce the energy barrier necessary to generate the active catalyst for the reaction [8]. This observation goes to prove the superiority of palladium, but the problems associated with phosphine ligands still remain and hence the continued search for nonphosphine palladium Heck coupling catalysts.

There are several considerations to be taken into account when identifying a good phosphine-free palla- 
dium catalyst. These include the cost of the ligand, the sensitivity of the ligand and the palladium complex to air and moisture, and the ability to adjust steric and electronic properties of the ligand in order to adequately coordinate to the palladium. Such conditions would allow for the use of stiochiometric quantities of the ligand and a palladium salt, or of well defined palladium complexes of a ligand. With this in mind, we have embarked on using pyrazolyl palladium complexes as catalysts for Heck coupling reactions and report some of our findings in this paper. The pyrazolyl ligands we used are known but their palladium complexes are new.

Poly(pyrazol-1-ylmethyl)benzene compounds were first reported in 1995 by Hartshorn and Steel [9] and described as having the potential to exhibit a variety of coordination modes. However, to date some of these expected modes are yet to be realised. For palladium only two of the expected coordination modes have been found when the ligands react with palladium salts. A complex with a cage structure containing six $\mathrm{PdCl}_{2}$ units and four 1,3,5-tris(pyrazol-1-ylmethyl)2,4,6-triethylbenzene units is formed when 1,3,5tris(pyrazol-1-ylmethyl)-2,4,6-triethylbenzene reacts with $\mathrm{PdCl}_{2}$ [10]. In this cage complex the $\mathrm{PdCl}_{2}$ fragments are bonded to the pyrazolyl units in a fashion that resembles the bonding in bis(pyrazole)palladium dihalides [11]. The second structurally characterised palladium complexes with these ligands are systems where $\mathrm{C}-\mathrm{H}$ activation in the benzene linker occurs; thus coordination of the ligand to the palladium atom occurs via pyrazolyl nitrogen atoms as well as through direct palladium-carbon bonds [12]. Otherwise the only other palladium complex structurally characterised is a tetrachloropalladate salt of the diprotonated form of 1,4-bis(3,5-dimethylpyrazol-1yl)-2,3,5,6-tetramethylbenzene [9]. In this paper we have demonstrated that depending on the position of the pyrazol-1-ylmethyl group on the benzene linker, the ligands can coordinate to palladium fragments such as two independent pyrazoles [11] and similar to the structure reported by Steel et al. [10], or as chelators to form metallocyclophanes, without $\pi$-interaction with the benzene ring, as proposed by Steel [9]. The latter structure is reminiscent of structures we recently reported for $\left[\mathrm{Pd}_{2} \mathrm{Cl}_{2}(\mu-\mathrm{Cl})_{2}\left(3,5-{ }^{t} \mathrm{BupzCO}\right)_{2}-1,3-\mathrm{C}_{6} \mathrm{H}_{3}\right]$ and $\left[\mathrm{Pd}_{2} \mathrm{Cl}_{2}(\mu-\mathrm{Cl})_{2}\left(3,5-{ }^{t} \mathrm{BupzCO}\right)_{3}-1,3,5-\mathrm{C}_{6} \mathrm{H}_{3}\right]$ [13]. We have used the pyrazolyl palladium complexes synthesised in this paper to further demonstrate that the complexes are efficient Heck coupling catalysts

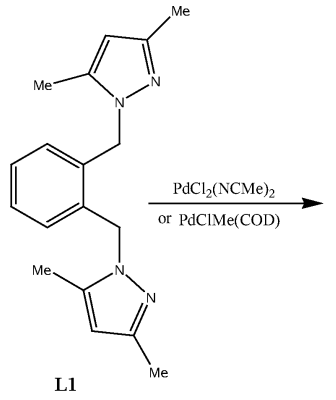

Scheme 1.

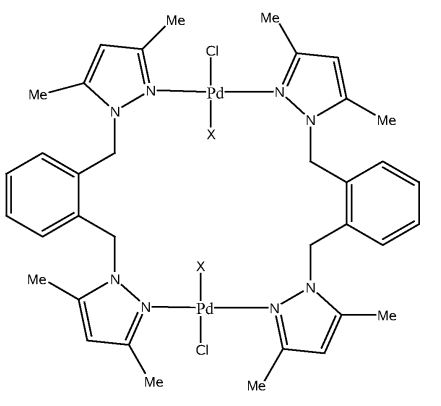

$(\mathrm{X}=\mathrm{Cl}(\mathbf{1}), \mathrm{Me}(\mathbf{2}))$

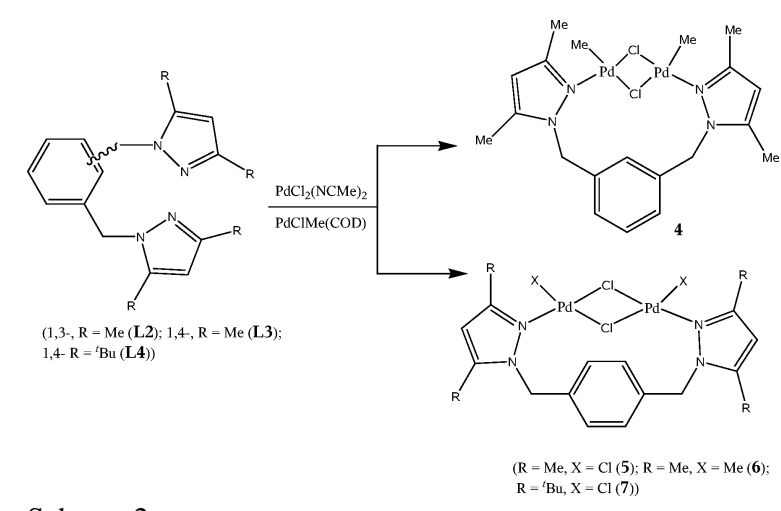

Scheme 2.

at a mild temperature to show that they are viable alternatives to palladium phosphine Heck catalysts.

\section{Results and Discussion}

Synthesis of palladium complexes

Five pyrazol-1-ylmethyl-benzene ligands (L1 - L5) were reacted with either $\left[\mathrm{PdCl}_{2}(\mathrm{NCMe})_{2}\right]$ or $[\mathrm{Pd}-$ $\mathrm{ClMe}(\mathrm{COD})]$ to form two types of complexes. Ligands L1 - L4 differ in the manner in which the bis(pyrazol1-ylmethyl) units are attached to the benzene linker and the nature of the pyrazole (Schemes 1 and 2), while ligand L5 has four (pyrazol-1-ylmethyl) units linked to benzene at positions 1, 2, 4 and 5. Ligand $\mathbf{L 1}$ reacted with both palladium starting materials to form a ring complex in which the pyrazolyl units on the ligand are bonded to different palladium atoms forming cyclic compounds (Scheme 1). The other ligands (L2-L5) on the other hand formed bimetallic palladium complexes (Scheme 2), in which the complexes are stabilised through bridging chlorides; except for the reaction of $\mathbf{L 3}$ with $\left[\mathrm{PdCl}_{2}(\mathrm{NCMe})_{2}\right]$ which appears to follow the way $\mathbf{L} \mathbf{1}$ forms complexes with palladium(II). In the case of $\mathbf{L 5}$ a bis(dipalladium) com- 
Table 1. Crystal data and structure refinement for 1, 2 and $\mathbf{8 .}$

\begin{tabular}{|c|c|c|c|}
\hline & 1 & 2 & 8 \\
\hline Empirical formula & $\mathrm{C}_{36} \mathrm{H}_{44} \mathrm{Cl}_{4} \mathrm{~N}_{8} \mathrm{Pd}_{2} \cdot \mathrm{CH}_{2} \mathrm{Cl}_{2}$ & $\mathrm{C}_{38} \mathrm{H}_{50} \mathrm{Cl}_{2} \mathrm{~N}_{8} \mathrm{Pd}_{2} \cdot\left(\mathrm{CH}_{2} \mathrm{Cl}_{2}\right)_{2}$ & $\mathrm{C}_{30} \mathrm{H}_{38} \mathrm{Cl}_{8} \mathrm{~N}_{8} \mathrm{Pd}_{4} \cdot\left(\mathrm{CH}_{2} \mathrm{Cl}_{2}\right)_{2}$ \\
\hline Formula weight & 1028.32 & 1072.41 & 1389.74 \\
\hline Temperature $[\mathrm{K}]$ & $100(2)$ & $100(2)$ & $100(2)$ \\
\hline Wavelength [̊] & 0.71073 & 0.71073 & 0.71073 \\
\hline Crystal system & monoclinic & monoclinic & monoclinic \\
\hline Space group & $P 2_{1}$ & $P 2_{1} / n$ & $C 2 / c$ \\
\hline$a[\AA]$ & $9.8705(13)$ & $13.3392(14)$ & $22.413(3)$ \\
\hline$b[\AA]$ & $14.828(2)$ & $12.4275(13)$ & $10.5328(13)$ \\
\hline$c[\AA]$ & $15.120(2)$ & $13.9384(15)$ & $21.605(3)$ \\
\hline$\beta[\mathrm{deg}]$ & $102.251(2)$ & $94.1520(10)$ & $114.6968(17)$ \\
\hline Volume $\left[\AA^{3}\right]$ & $2162.4(5)$ & $2304.5(4)$ & $4634.0(10)$ \\
\hline$Z$ & 2 & 2 & 4 \\
\hline$D_{\text {calc. }}\left[\mathrm{Mg} \mathrm{m}^{-3}\right]$ & 1.579 & 1.545 & 1.992 \\
\hline Abs. coeff. $\left[\mathrm{mm}^{-1}\right]$ & 1.239 & 1.166 & 2.255 \\
\hline$F(000)[\mathrm{e}]$ & 1036 & 1088 & 2712 \\
\hline Crystal size $\left[\mathrm{mm}^{3}\right]$ & $0.39 \times 0.36 \times 0.30$ & $0.44 \times 0.42 \times 0.32$ & $0.43 \times 0.27 \times 0.13$ \\
\hline Refl. collected & 24974 & 32571 & 7741 \\
\hline Completeness to $\theta[\%]$ & 99.8 & 99.8 & 99.8 \\
\hline Goof on $F^{2}$ & 1.028 & 1.046 & 1.011 \\
\hline$R(I \geq 2 \sigma(I))$ & 0.0472 & 0.0262 & 0.0303 \\
\hline$w R 2(I \geq 2 \sigma(I))$ & 0.1104 & 0.0682 & 0.0715 \\
\hline$\Delta \rho_{\text {fin }}\left[\mathrm{e} \AA^{-3}\right]$ & $0.867 /-0.876$ & $0.759 /-0.417$ & $1.135 /-0.978$ \\
\hline
\end{tabular}

plex was formed. All palladium complexes of these ligands were isolated in moderate to very good yields, are stable to air and moisture and could be kept under ambient conditions without any signs of decomposition. The palladium complexes were characterised by a combination of NMR and elemental analysis, and in selected cases by X-ray crystallography.

One distinguishing feature in the NMR spectra of the palladium complexes is that the $\mathrm{CH}_{2}$ protons which appeared as singlets in the ligands appeared as $\mathrm{AB}$ doublets in the palladium complexes with geminal coupling constants ranging from 14.7 to $18.4 \mathrm{~Hz}$. Complex 1 showed two sets of $\mathrm{CH}_{2}$ linker $\mathrm{AB}$ doublets in a 30:70 intensity ratio. These doublet peaks were accompanied by sets of proton peaks for the benzene linker and the pyrazole rings in approximately the same intensity ratios; suggesting the presence of two isomers of $\mathbf{1}$ in solution in a 70:30 ratio. Complexes with pyrazolyl-methylene linker ligands are known to exist in chair and boat conformations with restricted rotations. This gives rise to different $\mathrm{CH}_{2}$ proton environments that can be used to identify the presence of these isomers. Examples of pyrazolyl-methylene linker metal complexes that have chair and boat conformers include $\left[\mathrm{Cu}\left\{\left(\mathrm{Me}_{2} \mathrm{pz}-\mathrm{CH}_{2}\right)_{2} \mathrm{py}\right\}\left(\mathrm{PPh}_{3}\right)\right]\left[\mathrm{ClO}_{4}\right]$ [14], $\left[\mathrm{Ru}\left(\eta^{6}-\right.\right.$ $\left.\left.\mathrm{C}_{6} \mathrm{H}_{6}\right)\left(\mathrm{Me}_{2} \mathrm{pz}-\mathrm{CH}_{2}\right)_{2} \mathrm{py} \mathrm{PF}_{6}\right]$ [15] and $\left[\mathrm{Pd}\left(\mathrm{Me}_{2} \mathrm{pz}-\right.\right.$ $\left.\mathrm{CH}_{2}\right)_{2}$ py] $\left[\mathrm{B}\left\{\mathrm{C}_{6} \mathrm{H}_{3}\left(\mathrm{CF}_{3}\right)_{2}\right\}_{4}\right]$ [16]. It is therefore con- ceivable that the two isomers of $\mathbf{1}$ could arise from similar conformational restrictions. It is equally possible that two isomers are formed from different orientations of the benzene linkers, where one isomer has its benzene linkers on one side of the mirror plane that runs through both palladium atoms in 1 (Fig. 1). The second isomer would have the benzene rings on either side of this plane as seen in the structure of $\mathbf{2}$ (Fig. 2). The NMR spectra observed for 2, 4 and $\mathbf{7}$, all of which have chloro and methyl ligands bonded to palladium, similarly suggest that they exist in solution as two isomers. Both pyrazolyl-methyl and Pd-methyl proton signal ratios suggest a ratio of $60: 40$.

The general pattern where 1,2-benzene linker ligands form the ring complexes (structures of $\mathbf{1}$ and 2) and the 1,4-benzene linker ligands form the chloro-bridged bimetallic complexes (structure of 8 ), appears to have been broken by complexes $\mathbf{3}$ and $\mathbf{4}$. After several elemental analyses of samples of $\mathbf{3}$ and $\mathbf{4}$ from different experiments, we concluded from the consistency of the $\mathrm{CHN}$ analyses that $\mathbf{3}$ has a structure similar to the solid state structures of $\mathbf{1}$, whereas $\mathbf{4}$ has a bimetallic structure similar to the one found in $\mathbf{8}$. A ring structure, similar to the one proposed for $\mathbf{3}$, was reported by Sorrell and Jameson [17] for the copper complex $\left[\mathrm{Cu}\left\{1,3-\mathrm{C}_{6} \mathrm{H}_{3}\left(\mathrm{CH}_{2} \mathrm{pz}\right)\right\}\right]_{2}{ }^{2+}$, and would therefore support our structural formulation of $\mathbf{3}$. Similarly the proposed structure of complex $\mathbf{4}$ is the same 
Table 2. Selected bond lengths ( $\mathrm{A}$ ) and bond angles (deg) for 1 .

\begin{tabular}{llll}
\hline $\mathrm{Pd}(1)-\mathrm{N}(1)$ & $1.988(8)$ & $\mathrm{Pd}(2)-\mathrm{N}(4)$ & $1.994(8)$ \\
$\mathrm{Pd}(1)-\mathrm{N}(5)$ & $2.025(8)$ & $\mathrm{Pd}(2)-\mathrm{N}(8)$ & $2.023(8)$ \\
$\mathrm{Pd}(1)-\mathrm{Cl}(1)$ & $2.2978(13)$ & $\mathrm{Pd}(2)-\mathrm{Cl}(4)$ & $2.3075(12)$ \\
$\mathrm{Pd}(1)-\mathrm{Cl}(2)$ & $2.3038(13)$ & $\mathrm{Pd}(2)-\mathrm{Cl}(3)$ & $2.3329(13)$ \\
$\mathrm{N}(1)-\mathrm{Pd}(1)-\mathrm{N}(5)$ & $178.5(2)$ & $\mathrm{N}(4)-\mathrm{Pd}(2)-\mathrm{N}(8)$ & $176.3(2)$ \\
$\mathrm{N}(1)-\mathrm{Pd}(1)-\mathrm{Cl}(1)$ & $89.32(18)$ & $\mathrm{N}(4)-\mathrm{Pd}(2)-\mathrm{Cl}(4)$ & $89.52(17)$ \\
$\mathrm{N}(5)-\mathrm{Pd}(1)-\mathrm{Cl}(1)$ & $89.3(2)$ & $\mathrm{N}(8)-\mathrm{Pd}(2)-\mathrm{Cl}(4)$ & $91.07(17)$ \\
$\mathrm{N}(1)-\mathrm{Pd}(1)-\mathrm{Cl}(2)$ & $91.86(18)$ & $\mathrm{N}(4)-\mathrm{Pd}(2)-\mathrm{Cl}(3)$ & $89.78(17)$ \\
$\mathrm{N}(5)-\mathrm{Pd}(1)-\mathrm{Cl}(2)$ & $89.5(2)$ & $\mathrm{N}(8)-\mathrm{Pd}(2)-\mathrm{Cl}(3)$ & $89.69(17)$ \\
$\mathrm{Cl}(1)-\mathrm{Pd}(1)-\mathrm{Cl}(2)$ & $178.79(6)$ & $\mathrm{Cl}(4)-\mathrm{Pd}(2)-\mathrm{Cl}(3)$ & $178.81(6)$ \\
\hline
\end{tabular}

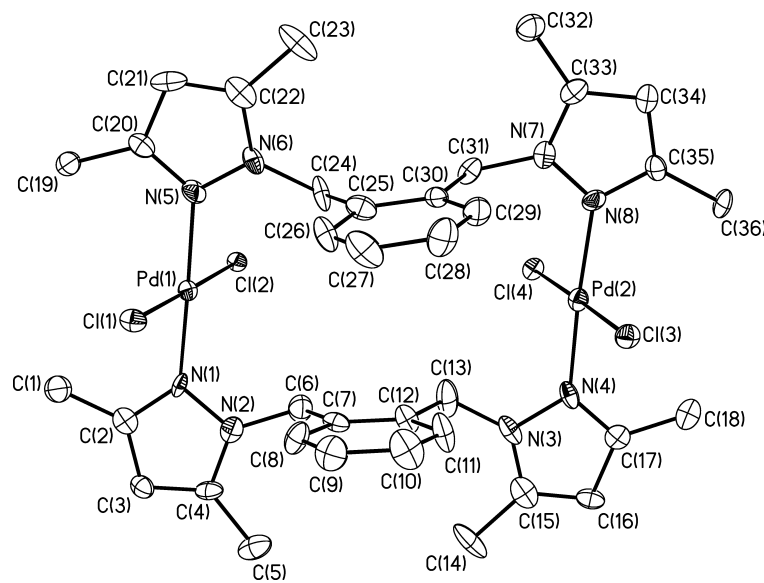

Fig. 1. Molecular structure of $\mathbf{1}$ shown with displacement ellipsoids at the $50 \%$ probability level.

as the structures of the palladium complexes, $\left[\mathrm{Pd}_{2}-\right.$ $\left.\mathrm{Cl}_{2}(\mu-\mathrm{Cl})_{2}\left(3,5-{ }^{t} \mathrm{BupzCO}\right)_{2}-1,3-\mathrm{C}_{6} \mathrm{H}_{3}\right]$ and $\left[\mathrm{Pd}_{2} \mathrm{Cl}_{2}-\right.$ $\left.(\mu-\mathrm{Cl})_{2}\left(3,5-{ }^{t} \mathrm{BupzCO}\right)_{3}-1,3,5-\mathrm{C}_{6} \mathrm{H}_{3}\right]$ [13]. Reaction of 1,3,5-tris(pyrazol-1-ylmethyl)-2,4-6-triethylbenzene with $\mathrm{PdCl}_{2}$ results in a three-dimensional structure in which two pyrazolyl units from different molecules are bonded to $\mathrm{PdCl}_{2}$ units [10], reminiscent of the bonding found in $\mathbf{1}$. It is not clear to us what dictates the structure of complexes with the ligand $\mathbf{L} \mathbf{2}$ when it reacts with a metal salt. It is likely to be dictated not only by the donor ability of the pyrazolyl nitrogen atoms, but by the other ligands present as well.

\section{Molecular structures of complexes 1, 2 and 8}

The molecular structures of complexes $\mathbf{1}, \mathbf{2}$ and $\mathbf{8}$ have been determined by single crystal X-ray crystallography. Crystal data and selected bond parameters are given in Tables 1-4.

Structure determination of $\mathbf{1}$ and $\mathbf{2}$ revealed that $\mathbf{L 1}$ formed complexes with palladium salts in which a pyrazolyl unit from different molecules of L1
Table 3. Selected bond lengths ( $)$ and bond angles (deg) for 2 .

\begin{tabular}{lcll}
\hline $\mathrm{Pd}(1)-\mathrm{C}(1)$ & $2.021(3)$ & $\mathrm{Pd}(1)-\mathrm{C}(1)$ & $2.021(3)$ \\
$\mathrm{Pd}(1)-\mathrm{N}(1)$ & $2.0261(19)$ & $\mathrm{Pd}(1)-\mathrm{Cl}(1)$ & $2.4616(6)$ \\
$\mathrm{Pd}(1)-\mathrm{N}(4) \# 1$ & $2.0268(19)$ & $\mathrm{Cl}(2)-\mathrm{C}(20)$ & $1.767(3)$ \\
$\mathrm{Pd}(1)-\mathrm{Cl}(1)$ & $2.4616(6)$ & $\mathrm{Cl}(3)-\mathrm{C}(20)$ & $1.759(3)$ \\
$\mathrm{C}(1)-\mathrm{Pd}(1)-\mathrm{N}(1)$ & $89.13(9)$ & $\mathrm{C}(3)-\mathrm{N}(1)-\mathrm{N}(2)$ & $106.19(18)$ \\
$\mathrm{C}(1)-\mathrm{Pd}(1)-\mathrm{N}(4) \# 1$ & $87.02(9)$ & $\mathrm{C}(3)-\mathrm{N}(1)-\mathrm{Pd}(1)$ & $129.72(16)$ \\
$\mathrm{N}(1)-\mathrm{Pd}(1)-\mathrm{N}(4) \# 1$ & $173.32(7)$ & $\mathrm{N}(2)-\mathrm{N}(1)-\mathrm{Pd}(1)$ & $123.76(14)$ \\
$\mathrm{C}(1)-\mathrm{Pd}(1)-\mathrm{Cl}(1)$ & $175.53(8)$ & $\mathrm{C}(5)-\mathrm{N}(2)-\mathrm{N}(1)$ & $110.96(18)$ \\
$\mathrm{N}(1)-\mathrm{Pd}(1)-\mathrm{Cl}(1)$ & $91.67(6)$ & $\mathrm{C}(5)-\mathrm{N}(2)-\mathrm{C}(7)$ & $128.2(2)$ \\
$\mathrm{N}(4) \# 1-\mathrm{Pd}(1)-\mathrm{Cl}(1)$ & $92.59(6)$ & $\mathrm{N}(1)-\mathrm{N}(2)-\mathrm{C}(7)$ & $119.37(18)$ \\
\hline
\end{tabular}

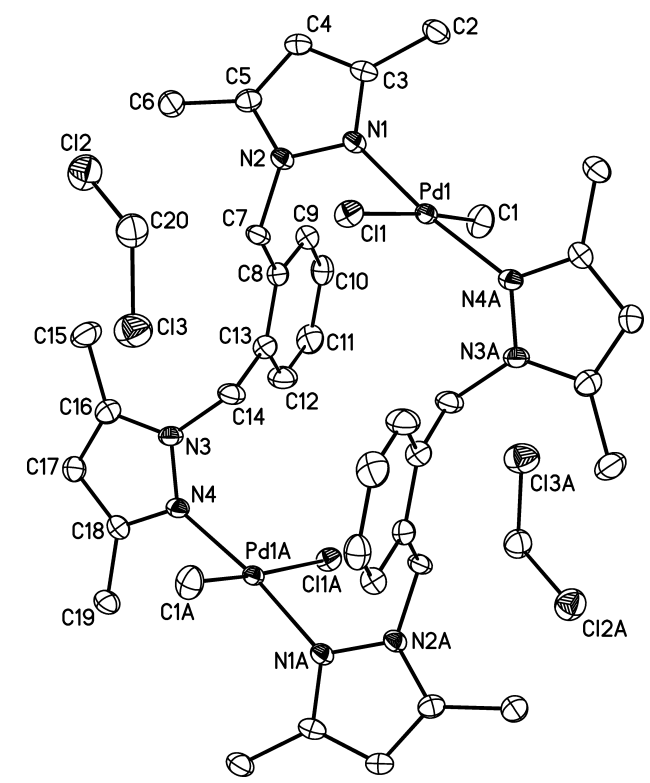

Fig. 2. Molecular structure of 2 with crystallographic inversion symmetry and displacement ellipsoids at the $50 \%$ probability level.

bind the same palladium atom (Figs. 1 and 2). Such binding of pyrazoles to palladium is well established for the bis(pyrazole) complexes $[\operatorname{Pd}(3,5-$ $\mathrm{Me}_{2} \mathrm{pz}_{2} \mathrm{Cl}_{2}$ ] and $\left[\mathrm{Pd}\left(3,5{ }^{-}{ }^{t} \mathrm{Bu}_{2} \mathrm{pz}\right)_{2} \mathrm{ClMe}\right]$ [11]. When the remaining set of pyrazolyl units in the two different molecules of $\mathbf{L} \mathbf{1}$ bind to a second palladium atom, this results in the ring structure found for $\mathbf{1}$ and 2. In both complexes the palladium atoms have a slightly distorted square planar coordination geometry, with angles being $\mathrm{N}(1)-\mathrm{Pd}(1)-\mathrm{Cl}(2) 91.86(18)^{\circ}(\mathbf{1})$ and $\mathrm{C}(1)-\mathrm{Pd}(1)-\mathrm{N}(4) \# 1$ 87.02(9) ${ }^{\circ}$ (2). Average bond lengths for $\mathrm{Pd}-\mathrm{Cl}$ and $\mathrm{Pd}-\mathrm{N}$ in $\mathbf{1}$ and $\mathbf{2}$ agree well with the average bond length of 2.33(5) A determined by averaging $2055 \mathrm{Pd}-\mathrm{Cl}$ bonds in 1268 relevant complexes and by averaging $607 \mathrm{Pd}-\mathrm{N}$ bonds in 229 relevant complexes reported to the CSD [18]. 
Table 4. Selected bond lengths $(\AA)$ and bond angles (deg) for 8 .

\begin{tabular}{lrlr}
\hline $\mathrm{Pd}(1)-\mathrm{N}(1)$ & $2.009(2)$ & $\mathrm{Pd}(2)-\mathrm{N}(3) \# 1$ & $2.012(3)$ \\
$\mathrm{Pd}(1)-\mathrm{Cl}(1)$ & $2.2913(8)$ & $\mathrm{Pd}(2)-\mathrm{Cl}(4)$ & $2.2846(8)$ \\
$\mathrm{Pd}(1)-\mathrm{Cl}(3)$ & $2.3122(8)$ & $\mathrm{Pd}(2)-\mathrm{Cl}(3)$ & $2.3121(8)$ \\
$\mathrm{Pd}(1)-\mathrm{Cl}(2)$ & $2.3632(8)$ & $\mathrm{Pd}(2)-\mathrm{Cl}(2)$ & $2.3729(8)$ \\
$\mathrm{N}(1)-\mathrm{Pd}(1)-\mathrm{Cl}(1)$ & $90.52(7)$ & $\mathrm{N}(3) \# 1-\mathrm{Pd}(2)-\mathrm{Cl}(3)$ & $173.78(7)$ \\
$\mathrm{N}(1)-\mathrm{Pd}(1)-\mathrm{Cl}(3)$ & $175.74(8)$ & $\mathrm{Cl}(4)-\mathrm{Pd}(2)-\mathrm{Cl}(3)$ & $91.33(3)$ \\
$\mathrm{Cl}(1)-\mathrm{Pd}(1)-\mathrm{Cl}(3)$ & $91.35(3)$ & $\mathrm{N}(3) \# 1-\mathrm{Pd}(2)-\mathrm{Cl}(2)$ & $93.77(7)$ \\
$\mathrm{N}(1)-\mathrm{Pd}(1)-\mathrm{Cl}(2)$ & $93.57(7)$ & $\mathrm{Cl}(4)-\mathrm{Pd}(2)-\mathrm{Cl}(2)$ & $174.88(3)$ \\
$\mathrm{Cl}(1)-\mathrm{Pd}(1)-\mathrm{Cl}(2)$ & $175.82(3)$ & $\mathrm{Cl}(3)-\mathrm{Pd}(2)-\mathrm{Cl}(2)$ & $84.41(3)$ \\
$\mathrm{Cl}(3)-\mathrm{Pd}(1)-\mathrm{Cl}(2)$ & $84.62(3)$ & $\mathrm{Pd}(1)-\mathrm{Cl}(2)-\mathrm{Pd}(2)$ & $87.37(3)$ \\
$\mathrm{N}(3) \# 1-\mathrm{Pd}(2)-\mathrm{Cl}(4)$ & $90.76(7)$ & $\mathrm{Pd}(2)-\mathrm{Cl}(2)-\mathrm{Pd}(2)$ & $90.05(3)$ \\
\hline
\end{tabular}

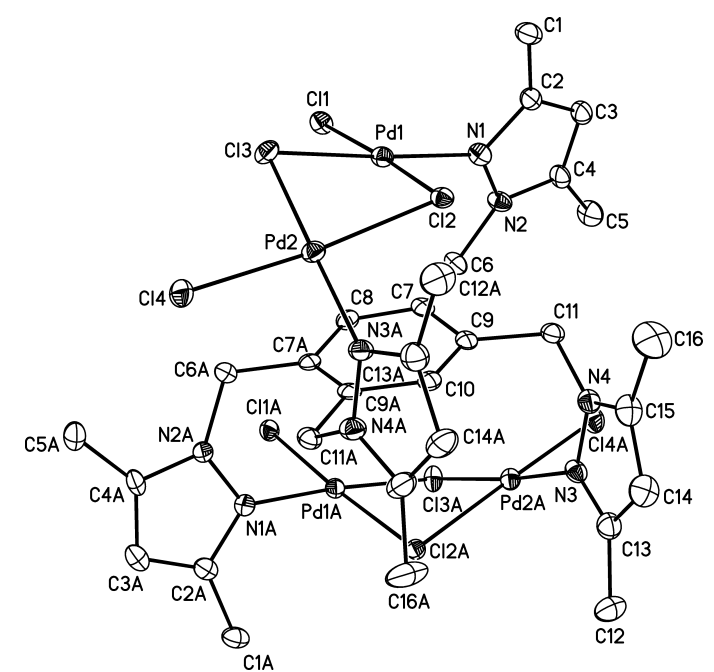

Fig. 3. Molecular structure of $\mathbf{8}$, the tetranuclear palladium complex resides on a crystallographic 2 -fold axis running through atoms $\mathrm{C} 8$ and $\mathrm{C} 10$.

The tetrametallic molecular structure found for $\mathbf{8}$ has two pairs of para-positioned pyrazolyl units spanning $\mathrm{Pd}_{2} \mathrm{Cl}_{4}$ fragments. One of the two $\mathrm{Pd}_{2} \mathrm{Cl}_{4}$ fragments is above the benzene linker to the four pyrazolyl-methylene units, whilst the other one is below (Fig. 3). Two examples of stabilised $\mathrm{Pd}_{2} X_{4}(X=$ $\mathrm{Cl}, \mathrm{Br}$ ) fragments are known in the literature. The first are $N$-heterocyclic carbene palladium compounds like $\left[\mathrm{Pd}_{2}(\mu-\mathrm{Br})_{2} \mathrm{Br}_{2}(\mathrm{NHC})_{2}\right]$ [19] in which the palladium centres are stabilised by bridging bromine atoms. The second is a group of complexes that have wide-span ligands which are stabilised across this ligand span by halide bridges like in $\left[\mathrm{Pd}_{2} \mathrm{Cl}_{2}(\mu-\mathrm{Cl})_{2}\left(3,5-{ }^{t} \mathrm{BupzCO}\right)_{2}\right.$ $\left.1,3-\mathrm{C}_{6} \mathrm{H}_{3}\right]$ and $\left[\mathrm{Pd}_{2} \mathrm{Cl}_{2}(\mu-\mathrm{Cl})_{2}\left(3,5-{ }^{t} \mathrm{BupzCO}\right)_{3}-1,3,5-\right.$ $\mathrm{C}_{6} \mathrm{H}_{3}$ ] [13]. The differences in terminal $\mathrm{Pd}-\mathrm{Cl}$ bond lengths are statistically insignificant and lie within the range found for terminal $\mathrm{Pd}-\mathrm{Cl}$ bonds. The bridging $\mathrm{Pd}-\mathrm{Cl}$ bonds in $\mathbf{8}$ similarly have bond lengths that do
Table 5. Results of the Heck coupling reactions.

\begin{tabular}{|c|c|c|c|c|}
\hline$\overline{\text { Entry }}$ & Catalyst & $\begin{array}{l}\text { Time } \\
\text { (h) }\end{array}$ & $\begin{array}{c}\text { Conversion } \\
(\%)^{\mathrm{a}}\end{array}$ & $\begin{array}{c}\text { TON } \\
(\mathrm{mol} \mathrm{product} / \mathrm{mol} \mathrm{Pd})\end{array}$ \\
\hline 1 & $\mathbf{1}$ & 0.5 & 80 & 84.16 \\
\hline 2 & 1 & 6.0 & 90 & 94.68 \\
\hline 3 & $\mathbf{1}$ & 24.0 & 92 & 96.72 \\
\hline 4 & 2 & 0.5 & 49 & 51.56 \\
\hline 5 & 2 & 6.0 & 79 & 83.10 \\
\hline 6 & 2 & 24.0 & 90 & 94.8 \\
\hline 7 & 3 & 0.5 & 79 & 83.13 \\
\hline 8 & 3 & 6.0 & 82 & 86.28 \\
\hline 9 & 3 & 24.0 & 83 & 87.36 \\
\hline 10 & 4 & 0.5 & 75 & 78.92 \\
\hline 11 & 4 & 6.0 & 80 & 84.18 \\
\hline 12 & 4 & 24.0 & 83 & 87.36 \\
\hline 13 & 5 & 0.5 & 26 & 27.25 \\
\hline 14 & 5 & 6.0 & 75 & 78.90 \\
\hline 15 & 5 & 24.0 & 87 & 91.44 \\
\hline 16 & 6 & 0.5 & 68 & 71.55 \\
\hline 17 & 6 & 6.0 & 92 & 96.78 \\
\hline 18 & 6 & 24.0 & 100 & 105.12 \\
\hline 19 & 7 & 0.5 & 32 & 33.67 \\
\hline 20 & 7 & 6.0 & 88 & 92.59 \\
\hline 21 & 7 & 24.0 & 89 & 93.25 \\
\hline 22 & 8 & 0.5 & 54 & 56.82 \\
\hline 23 & 8 & 6.0 & 84 & 88.39 \\
\hline 24 & 8 & 24.0 & 94 & 98.91 \\
\hline
\end{tabular}

${ }^{\text {a }}$ Determined by GC.

not differ much from bridging $\mathrm{Pd}-\mathrm{Cl}$ bonds in complexes with similar structures [13].

\section{Catalytic Heck reaction}

The palladium complexes $\mathbf{1}-\mathbf{8}$ were tested as catalysts for the Heck coupling reaction using the three halobenzenes (chloro, bromo, and iodo) and butylacrylate. Only iodobenzene gave any significant conversions to the cinnamate product (Table 5). It is noteworthy that the reaction occurs at a very mild temperature compared to most Heck reactions that are performed at $120-160{ }^{\circ} \mathrm{C}$. The low temperature at which the reaction was performed ensured there was no formation of palladium black characteristic of high temperature Heck reactions. With the exception of entries 4, 13 and 19 (Table 5) all the reactions had significant conversions within the first $30 \mathrm{~min}$ of the reaction; but for most reactions conversion of over $80 \%$ were found after $6 \mathrm{~h}$. This means that as catalysts for synthesis, one does not have to run the reactions longer that $6 \mathrm{~h}$ since after $6 \mathrm{~h}$ only small increases in conversion were observed even when reactions were run for up to $24 \mathrm{~h}$. No significant differences in conversions were found 
using complexes $\mathbf{1}-\mathbf{8}$, though the complexes with ring structures took a much longer time to reach maximum conversion; whilst 5-8 in particular catalysed the reaction to nearly $80 \%$ conversions within the first $2 \mathrm{~h}$.

Kawano et al. [2] have suggested that bidentate pyridine $\mathrm{Pd}(\mathrm{II})$ complexes catalyse Heck coupling reactions by first being reduced to ligand stabilised $\operatorname{Pd}(0)$ complexes, which are the active catalysts. In our reactions such a mechanism would lead to different catalytic activities for the types of ligands we have used. We see no significant differences in conversions when the reaction is allowed sufficient time, usually $24 \mathrm{~h}$. It therefore appears that in catalysing the Heck coupling reaction in Table 5 using $\mathbf{1 - 8}$ our reactions do not go via the mechanism suggested by Kawano et al. for Pd(II) catalysts [2]. It is conceivable that once the $\operatorname{Pd}(0)$ species are formed the only role that the ligands play is to stabilise the $\operatorname{Pd}(0)$ colloidal species to avoid aggregation to palladium black. De Vries has found such colloids to catalyse Heck coupling reactions [20]. Complexes 1-3 took much longer to reach maximum conversion, possibly because they are more difficult to be converted to $\operatorname{Pd}(0)$, the active species. The appeal, though, for the range of complexes tested here is the mild temperature at which they catalyse the Heck reaction as described in Table 5.

\section{Conclusions}

The poly(pyrazol-1-ylmethyl)benzene compounds used in this study form two types of palladium complexes for which the structure is determined by the span between the pyrazolyl units. For pyrazolyl ligands that have carbonyl linkers like $\left[\mathrm{Pd}_{2} \mathrm{Cl}_{2}(\mu-\mathrm{Cl})_{2}(3,5-\right.$ $\left.{ }^{t} \mathrm{BupzCO}\right)_{2}-1,3-\mathrm{C}_{6} \mathrm{H}_{3}$ ] [13] it would appear that the formation of chloro-bridged dipalladium structures is dictated by the reduced $\sigma$-donor ability of the nitrogen atoms. Indeed ortho-substituted pyrazol-1-yl-benzene ligands, in which the ortho substituent is either fluorine or chlorine, give rise to halide-bridged dipalladium structures as shown in recent structure determinations [21]. However, the structures of $\mathbf{1}$ and $\mathbf{2}$ on one hand and the structure of $\mathbf{8}$ on the other, point to the span between the pyrazolyl nitrogen atoms as another factor that determines the structure of pyrazolyl palladium complexes. All the palladium complexes, 1-8, were shown to be efficient catalysts for the Heck coupling reaction between iodobenzene and butylacrylate under very mild conditions and at moderate catalyst loading and provide yet another group of easy to pre- pare, air and moisture stable palladium Heck coupling catalysts.

\section{Experimental Section}

\section{Materials and instrumentation}

All reactions were performed under a dry nitrogen atmosphere using standard Schlenk techniques. Dichloromethane was dried over $\mathrm{P}_{2} \mathrm{O}_{5}$ and stored over molecular sieves. All ligands (L1-L5) were prepared following a literature procedure described by Steel and Hartshorn [9]. $\left[\mathrm{PdCl}_{2}(\mathrm{NCMe})_{2}\right]$ [22] and [PdClMe(COD)] [23] were prepared as described in the literature. NMR spectra were recorded on a Varian Gemini 2000 instrument $\left({ }^{1} \mathrm{H}\right.$ at $200 \mathrm{MHz}$ and ${ }^{13} \mathrm{C}$ at $50.1 \mathrm{MHz}$ ). Chemical shifts are reported in $\delta(\mathrm{ppm})$ and referenced to the signal of the residual protons of deuterated chloroform as internal standard.

\section{Synthesis of palladium complexes}

Bis(di\{1,2-bis(3,5-dimethylpyrazol-1-ylmethyl)benzene\})tetrachlorodipalladium (1)

To a solution of $\left[\mathrm{PdCl}_{2}(\mathrm{NCMe})_{2}\right](0.44 \mathrm{~g}, 1.70 \mathrm{mmol})$ in $\mathrm{CH}_{2} \mathrm{Cl}_{2}(40 \mathrm{~mL})$ was added $\mathbf{L 1}(0.50 \mathrm{~g}, 1.70 \mathrm{mmol})$. The resultant orange solution was stirred for $8 \mathrm{~h}$ and after concentrating the solution to half its volume, an equal volume of hexane was added to precipitate a yellow solid. Recrystallisation from $\mathrm{CH}_{2} \mathrm{Cl}_{2}$-hexane at $-4{ }^{\circ} \mathrm{C}$ gave yellow crystals. Yield: $0.53 \mathrm{~g}(56 \%) .-{ }^{1} \mathrm{H} \mathrm{NMR}\left(\mathrm{CDCl}_{3}\right): \delta=2.39$ (s, $\left.12 \mathrm{H}, \mathrm{CH}_{3}, \mathrm{pz}\right), 2.42$ (s, 12H, $\left.\mathrm{CH}_{3}, \mathrm{pz}\right), 2.54\left(\mathrm{~s}, 12 \mathrm{H}, \mathrm{CH}_{3}\right.$, pz), $2.57\left(\mathrm{~s}, 12 \mathrm{H}, \mathrm{CH}_{3}, \mathrm{pz}\right), 4.64\left(\mathrm{~d}, \mathrm{CH}_{2},{ }^{2} \mathrm{~J}=15.3 \mathrm{~Hz}\right)$, $5.29\left(\mathrm{~d}, \mathrm{CH}_{2},{ }^{2} J=15.3 \mathrm{~Hz}\right), 5.85(\mathrm{~s}, 4 \mathrm{H}, 4-\mathrm{pz}), 5.87$ (s, $4 \mathrm{H}, 4-\mathrm{pz}), 6.87\left(\mathrm{~d}, \mathrm{CH}_{2},{ }^{2} \mathrm{~J}=15.3 \mathrm{~Hz}\right), 7.10(\mathrm{~m}, \mathrm{Ph}), 7.27$ $(\mathrm{m}, \mathrm{Ph}), 7.40(\mathrm{~m}, \mathrm{Ph}), 7.55(\mathrm{~m}, \mathrm{Ph}), 7.86\left(\mathrm{~d}, \mathrm{CH}_{2},{ }^{2} J=\right.$ $15.3 \mathrm{~Hz}) .-\mathrm{C}_{36} \mathrm{H}_{44} \mathrm{Cl}_{4} \mathrm{~N}_{8} \mathrm{Pd}_{2} \cdot 0.5 \mathrm{CH}_{2} \mathrm{Cl}_{2}$ : calcd. C 44.47, $\mathrm{H}$ 4.60, N 11.36; found C 44.13, H 4.56, N 11.15.

Complexes $\mathbf{2}-\mathbf{5}$ were synthesised in a similar manner as described for complex $\mathbf{1}$.

\section{Di\{1,2-bis(3,5-dimethylpyrazol-1-ylmethyl)benzene\}- dichlorodimethyldipalladium (2)}

Complex 2 was prepared from [PdClMe(COD)] (0.50 g, $0.1 .96 \mathrm{mmol})$ and $\mathbf{L 2}(0.51 \mathrm{~g}, 1.70 \mathrm{mmol})$ in $\mathrm{Et}_{2} \mathrm{O}(40 \mathrm{~mL})$. Yield: $0.63 \mathrm{~g}(40 \%) .-{ }^{1} \mathrm{H} \mathrm{NMR}\left(\mathrm{CDCl}_{3}\right): \delta=0.33(\mathrm{~s}$, $3 \mathrm{H}, \mathrm{Pd}-\mathrm{CH}_{3}$ ), 1.98 (s, 12H, $\left.\mathrm{CH}_{3}, \mathrm{pz}\right), 2.69$ (s, 12H, $\mathrm{CH}_{3}$, pz), $5.29\left(\mathrm{~d}, 2 \mathrm{H},-\mathrm{CH}_{2},{ }^{2} \mathrm{~J}=18.0 \mathrm{~Hz}\right), 5.92(\mathrm{~s}, 4 \mathrm{H}, 4-\mathrm{pz})$, $6.46\left(\mathrm{~d}, 2 \mathrm{H},-\mathrm{CH}_{2},{ }^{2} J=17.11 \mathrm{~Hz}\right), 6.84(\mathrm{~m}, 4 \mathrm{H}, \mathrm{Ph})$, $7.18(\mathrm{~m}, 4 \mathrm{H}, \mathrm{Ph}) .-{ }^{13} \mathrm{C}\left\{{ }^{1} \mathrm{H}\right\} \mathrm{NMR}\left(\mathrm{CDCl}_{3}\right): \delta=-5.0$, 11.7, 15.2, 52.7, 107.1, 125.5, 126.7, 135.5, 141.8, 149.0. $-\mathrm{C}_{38} \mathrm{H}_{50} \mathrm{Cl}_{2} \mathrm{~N}_{8} \mathrm{Pd}_{2}$ : calcd. C 50.57, H 5.58, N 12.41; found C 50.17, H 5.74, N 12.07 . 
Bis(di\{1,3-bis(3,5-dimethylpyrazol-1-ylmethyl)benzene\})tetrachlorodipalladium (3)

This compound was prepared from $\left[\mathrm{PdCl}_{2}(\mathrm{NCMe})_{2}\right]$ (0.44 g, $1.70 \mathrm{mmol})$ and $\mathbf{L 2}(0.50 \mathrm{~g}, 1.70 \mathrm{mmol})$. Yield: $0.48 \mathrm{~g}(51 \%) .-{ }^{1} \mathrm{H} \mathrm{NMR}\left(\mathrm{CDCl}_{3}\right): \delta=2.06\left(\mathrm{~s}, 6 \mathrm{H}, \mathrm{CH}_{3}\right.$, pz), $2.91\left(\mathrm{~s}, 6 \mathrm{H}, \mathrm{CH}_{3}, \mathrm{pz}\right), 5.77\left(\mathrm{~s}, 4 \mathrm{H}, \mathrm{CH}_{2}\right), 5.92(\mathrm{~s}, 2 \mathrm{H}$, 4-pz), 7.09 (m, 2H, Ph), $7.40(\mathrm{~m}, 1 \mathrm{H}, \mathrm{Ph}), 7.74(\mathrm{~m}, 1 \mathrm{H}, \mathrm{Ph})$. ${ }^{13} \mathrm{C}\left\{{ }^{1} \mathrm{H}\right\}$ NMR $\left(\mathrm{CDCl}_{3}\right): \delta=12.1,15.3,52.8,108.1,126.9$, 129.2, 135.7, 143.8, 150.6. $-\mathrm{C}_{36} \mathrm{H}_{44} \mathrm{Cl}_{4} \mathrm{~N}_{8} \mathrm{Pd}_{2} \cdot 0.5 \mathrm{CH}_{2} \mathrm{Cl}_{2}$ : calcd. C 44.47, H 4.60, N 11.36; found C 44.13, H 4.56, $\mathrm{N} 11.15$.

\section{Di- $\mu$-chloro-dimethyl $\{1,3-$ bis(3,5-dimethylpyrazol-1-yl- methyl)benzene dipalladium (4)}

Complex 4 was prepared from [PdClMe(COD)] (0.50 g, $0.1 .96 \mathrm{mmol})$ in $\mathrm{Et}_{2} \mathrm{O}(40 \mathrm{~mL})$ and $\mathbf{L 2}(0.25 \mathrm{~g}, 0.85 \mathrm{mmol})$. A beige precipitate was formed in $6 \mathrm{~h}$ and the product was isolated as a beige solid. Yield: $0.65 \mathrm{~g}(84 \%) .-{ }^{1} \mathrm{H}$ NMR $\left(\mathrm{CDCl}_{3}\right): \delta=0.33$ (s, 3H, $\left.\mathrm{Pd}-\mathrm{CH}_{3}\right), 1.95\left(\mathrm{~s}, 6 \mathrm{H}, \mathrm{CH}_{3}, \mathrm{pz}\right)$, $2.67\left(\mathrm{~s}, 6 \mathrm{H}, \mathrm{CH}_{3}, \mathrm{pz}\right), 5.33\left(\mathrm{~d}, 2 \mathrm{H}, \mathrm{CH}_{2},{ }^{2} J=16.8 \mathrm{~Hz}\right), 5.27$ (d, $\left.2 \mathrm{H}, \mathrm{CH}_{2},{ }^{2} \mathrm{~J}=16.8 \mathrm{~Hz}\right), 5.91$ (s, 2H, 4-pz), 6.45 (d, 2H, $\left.\mathrm{Ph},{ }^{2} J=16.9 \mathrm{~Hz}\right), 6.89(\mathrm{~m}, 1 \mathrm{H}, \mathrm{Ph}), 7.15(\mathrm{~m}, 1 \mathrm{H}, \mathrm{Ph})$. ${ }^{13} \mathrm{C}\left\{{ }^{1} \mathrm{H}\right\} \mathrm{NMR}\left(\mathrm{CDCl}_{3}\right): \delta=-4.3,11.9,15.3,53.4,107.4$, 124.3, 125.4, 129.3, 136.7, 142.0, 149.2.

\section{Di- $\mu$-chloro-dichloro\{1,4-bis(3,5-dimethylpyrazol-1-yl- methyl)benzene\} dipalladium (5)}

This compound was prepared from $\left[\mathrm{PdCl}_{2}(\mathrm{NCMe})_{2}\right]$ (0.44 g, $1.70 \mathrm{mmol})$ and $\mathbf{L 3}(0.25 \mathrm{~g}, 0.085 \mathrm{mmol})$. The product was isolated as a brown solid. Yield: $0.46 \mathrm{~g}(83 \%)$. $-{ }^{1} \mathrm{H} \mathrm{NMR}\left(\mathrm{CDCl}_{3}\right): \delta=2.48\left(\mathrm{~s}, 6 \mathrm{H}, \mathrm{CH}_{3}, \mathrm{pz}\right), 2.59$ (s, 6H, $\left.\mathrm{CH}_{3}, \mathrm{pz}\right), 5.48\left(\mathrm{~d}, 2 \mathrm{H}, \mathrm{CH}_{2},{ }^{2} J=14.7 \mathrm{~Hz}\right), 5.76$ (d, $\left.2 \mathrm{H}, \mathrm{CH}_{2},{ }^{2} \mathrm{~J}=15.0 \mathrm{~Hz}\right), 5.86(\mathrm{~s}, 2 \mathrm{H}, 4-\mathrm{pz}), 6.86$ (s, $2 \mathrm{H}, \mathrm{Ph}), 8.95(\mathrm{~s}, 2 \mathrm{H}, \mathrm{Ph}) .-{ }^{13} \mathrm{C}\left\{{ }^{1} \mathrm{H}\right\} \mathrm{NMR}\left(\mathrm{CDCl}_{3}\right): \delta=$ 12.6, 15.5, 52.2, 107.3, 129.6, 134.5, 136.8, 144.5, 152.0. $-\mathrm{C}_{18} \mathrm{H}_{22} \mathrm{Cl}_{4} \mathrm{~N}_{4} \mathrm{Pd}_{2}$ : calcd. C 33.31, H 3.42, N 8.63; found C 34.74, H 3.66, N 9.04.

Di- $\mu$-chloro-dimethyl-di 1,4-bis(3,5-dimethylpyrazol-1-ylmethyl)benzene\} dipalladium (6)

Compound 6 was prepared from [PdClMe(COD)] (0.50 g, $1.96 \mathrm{mmol})$ and $\mathbf{L 3}(0.25 \mathrm{~g}, 0.85 \mathrm{mmol})$ in $\mathrm{Et}_{2} \mathrm{O}(40 \mathrm{~mL})$. A white precipitate formed during $6 \mathrm{~h}$ of stirring. The precipitate was filtered, dried and recrystallised from $\mathrm{CH}_{2} \mathrm{Cl}_{2}$ hexane at $-4{ }^{\circ} \mathrm{C}$. Yield: $0.50 \mathrm{~g}(97 \%) .-{ }^{1} \mathrm{H} \mathrm{NMR}\left(\mathrm{CDCl}_{3}\right)$ : $\delta=-0.06$ (s, $\left.3 \mathrm{H}, \mathrm{CH}_{3}, \mathrm{Pd}\right), 0.31$ (s, $\left.3 \mathrm{H}, \mathrm{CH}_{3}, \mathrm{Pd}\right), 2.05$ (s, 6H, $\left.\mathrm{CH}_{3}, \mathrm{pz}\right), 2.09$ (s, 6H, $\left.\mathrm{CH}_{3}, \mathrm{pz}\right), 2.62$ (s, 6H, $\left.\mathrm{CH}_{3}, \mathrm{pz}\right), 2.68\left(\mathrm{~s}, 6 \mathrm{H}, \mathrm{CH}_{3}, \mathrm{pz}\right), 5.12\left(\mathrm{~d}, 2 \mathrm{H}, \mathrm{CH}_{2},{ }^{2} J=\right.$ $18.4 \mathrm{~Hz}), 5.21\left(\mathrm{~d}, 2 \mathrm{H}, \mathrm{CH}_{2},{ }^{2} J=17.6 \mathrm{~Hz}\right), 5.91(\mathrm{~s}, 2 \mathrm{H}$, 4-pz), 5.94 (s, 2H, 4-pz), 6.66 (s, 2H, Ph), 6.84 (s, 2H, $\mathrm{Ph}), 6.94\left(\mathrm{~d}, 2 \mathrm{H}, \mathrm{CH}_{2},{ }^{2} \mathrm{~J}=17.1 \mathrm{~Hz}\right), 7.08\left(\mathrm{~d}, 2 \mathrm{H}, \mathrm{CH}_{2}\right.$, $\left.{ }^{2} J=16.8 \mathrm{~Hz}\right) .-{ }^{13} \mathrm{C}\left\{{ }^{1} \mathrm{H}\right\} \mathrm{NMR}\left(\mathrm{CDCl}_{3}\right): \delta=-4.0,-5.0$, 11.7, 12.0, 15.2, 15.3, 52.7, 53.3, 107.1, 107.3, 125.5, 126.7, 135.4, 141.8, 149.0. $-\mathrm{C}_{38} \mathrm{H}_{50} \mathrm{Cl}_{2} \mathrm{~N}_{8} \mathrm{Pd}_{2} \cdot 0.5 \mathrm{CH}_{2} \mathrm{Cl}_{2}$ : calcd. C 48.93, H 5.43, N 11.86; found C 49.05, H 5.60, N 11.33.

Di- $\mu$-chloro-dichloro\{1,4-bis(3,5-ditertbutylpyrazol-1-ylmethyl)benzene dipalladium (7)

This compound was prepared from $\left[\mathrm{PdCl}_{2}(\mathrm{NCMe})_{2}\right]$ $(0.44 \mathrm{~g}, 1.07 \mathrm{mmol})$ and $\mathbf{L} 4(0.25 \mathrm{~g}, 0.54 \mathrm{mmol})$. The product was obtained as an orange solid. Yield: $0.48 \mathrm{~g}(70 \%)$. - ${ }^{1} \mathrm{H}$ NMR $\left(\mathrm{CDCl}_{3}\right): \delta=1.48\left(\mathrm{~s}, 18 \mathrm{H},{ }^{t} \mathrm{Bu}, \mathrm{pz}\right), 1.75$ (s, $\left.18 \mathrm{H},{ }^{t} \mathrm{Bu}, \mathrm{pz}\right), 5.93(\mathrm{~s}, 2 \mathrm{H}, 4-\mathrm{pz}), 5.95\left(\mathrm{~d}, 2 \mathrm{H}, \mathrm{CH}_{2},{ }^{2} J=\right.$ $15.3 \mathrm{~Hz}), 6.06\left(\mathrm{~d}, 2 \mathrm{H}, \mathrm{CH}_{2},{ }^{2} J=15.6 \mathrm{~Hz}\right), 7.09(\mathrm{~s}, 2 \mathrm{H}$, $\mathrm{Ph}), 8.86(\mathrm{~s}, 2 \mathrm{H}, \mathrm{Ph}) .-{ }^{13} \mathrm{C}\left\{{ }^{1} \mathrm{H}\right\}$ NMR $\left(\mathrm{CDCl}_{3}\right): \delta=31.6$, 32.1, 32.8, 54.4, 103.7, 104.2, 129.9, 133.9, 134.9, 136.2, 136.3, 156.5, 157.9, 164.2, 165.5. $-\mathrm{C}_{30} \mathrm{H}_{46} \mathrm{Cl}_{4} \mathrm{~N}_{4} \mathrm{Pd}_{2}$ : calcd. C 44.08, H 5.67, N 6.85; found C 43.60, H 5.64, N 6.71.

Di- $\mu$-chloro-dichloro\{1,2,4,5-tetrakis(3,5-dimethylpyrazol1-ylmethyl)benzene dipalladium (8)

Complex 8 was prepared from $\left[\mathrm{PdCl}_{2}(\mathrm{NCMe})_{2}\right](0.50 \mathrm{~g}$, $1.96 \mathrm{mmol})$ and $\mathbf{L 5}(0.25 \mathrm{~g}, 0.49 \mathrm{mmol})$. Orange crystals were obtained from a solution of a $1: 1 \mathrm{CH}_{2} \mathrm{Cl}_{2}$-hexane at $-4{ }^{\circ} \mathrm{C}$. Yield: $0.50 \mathrm{~g}(84 \%) .-{ }^{1} \mathrm{H} \mathrm{NMR}\left(\mathrm{CDCl}_{3}\right), \delta=1.91$ (s, 6H, $\left.\mathrm{CH}_{3}, \mathrm{pz}\right), 2.51$ (s, 6H, $\left.\mathrm{CH}_{3}, \mathrm{pz}\right), 2.64$ (s, 6H, $\mathrm{CH}_{3}, \mathrm{pz}$ ), $2.81\left(\mathrm{~s}, 6 \mathrm{H}, \mathrm{CH}_{3}, \mathrm{pz}\right), 3.95\left(\mathrm{~d}, 2 \mathrm{H}, \mathrm{CH}_{2},{ }^{2} \mathrm{~J}=16.2 \mathrm{~Hz}\right), 5.30$ (s, 2H, 4-pz), 5.63 (d, 2H, $\mathrm{CH}_{2},{ }^{2} \mathrm{~J}=15.6 \mathrm{~Hz}$ ), 5.77 (s, 2H, $\mathrm{Ph}$ ), 6.00 (s, 2H, 4-pz), 6.03 (d, 2H, $\left.\mathrm{CH}_{2},{ }^{2} J=16.5 \mathrm{~Hz}\right), 6.65$ $\left(\mathrm{d}, 2 \mathrm{H}, \mathrm{CH}_{2},{ }^{2} \mathrm{~J}=15.0 \mathrm{~Hz}\right) .-{ }^{13} \mathrm{C}\left\{{ }^{1} \mathrm{H}\right\} \mathrm{NMR}\left(\mathrm{CDCl}_{3}\right), \delta=$ 11.7, 15.2, 52.7, 107.1, 125.5, 126.7, 135.5, 141.8, 149.0. $\mathrm{C}_{30} \mathrm{H}_{38} \mathrm{Cl}_{8} \mathrm{~N}_{8} \mathrm{Pd}_{4} \cdot 2 \mathrm{CH}_{2} \mathrm{Cl}_{2}$ : calcd. C 27.65, H 3.04, N 8.06; found $\mathrm{C} 27.85, \mathrm{H} 2.97, \mathrm{~N} 8.11$.

\section{X-Ray structural determination}

The crystal data collection for $\mathbf{1 , 2}$ and $\mathbf{8}$ as performed on a Bruker CCD-1000 diffractometer with $\operatorname{Mo} K_{\alpha}$ radiation $(\lambda=0.71073 \AA)$ and a diffractometer to crystal distance of $4.9 \mathrm{~cm}$. The initial cell constants were obtained from three series of $\omega$ scans at different starting angles. Each series consisted of 20 frames collected at intervals of $0.3^{\circ}$ in a $6^{\circ}$ range about $\omega$ with the exposure time of 10 seconds per frame. The reflections were successfully indexed by an automated indexing routine built in the SMART program. Highly redundant data sets were corrected for Lorentz and polarisation effects and absorption correction was based on fitting a function to the empirical transmission surface as sampled by multiple equivalent measurements [24]. The structures were solved by Direct Methods and refined by least squares techniques using the SHELXTL program [24]. All non-hydrogen atoms were refined with anisotropic displacement coefficients. All hydrogen atoms were included in the structure factor calculation at idealised 
positions and were allowed to ride on the neighbouring atoms with relative isotropic displacement coefficients. Crystals of complex 1 contain one molecule of dichloromethane per formula unit. The solvent molecule is disordered over two positions in a $87: 13$ ratio. The crystal proved to be twinned with a 58:42 component ratio. For complex 2, there are two dichloromethane solvate molecules per formula unit. Similarly, complex $\mathbf{8}$ has two dichloromethane solvate molecules per tetranuclear complex, each of them disordered over three positions in a 0.50:0.39:0.11 ratio (refined with restraints). Additionally, the crystal proved to be a non-merohedral twin with a $78: 22$ component ratio.

CCDC $625984 ; 625985$ and 625986 contain the supplementary crystallographic data for $\mathbf{1}, \mathbf{2}$, and $\mathbf{8}$; respectively. These data can be obtained free of charge from The Cambridge Crystallographic Data Centre via www.ccdc.cam.ac.uk/data_request/cif.

\section{Acknowledgement}

We gratefully acknowledge funding by the National Research Foundation (South Africa) for this project.
[1] a) S. Ittel, M. Brookhart, L. K. Johnson, Chem. Rev. 2000, 100, 1169; b) S. Mecking, Coord. Chem. Rev. 2000, 203, 325; c) V. C. Gibson, S. K. Spitzmesser, Chem. Rev. 2003, 103, 283; d) C. Bianchini, G. Giambastiani, I. G. Rios, G. Mantovani, A. Meli, A. M. Segarra, Coord. Chem. Rev. 2006, 250, 1391.

[2] T. Kawano, T. Shinomaru, I. Ueda, Org. Lett. 2002, 4, 2545.

[3] a) J.-C. Xiao, B. Twamley, J. M. Shreeve, Org. Lett. 2004, 6, 3845; b) D. Domin, D. Benito-Garagorri, K. Mereiter, J. Frohlich, K. Kirchner, Organometallics 2005, 24, 3957; c) S. B. Park, H. Alper, Org. Lett. 2003, 5,3209 .

[4] a) W. A. Herrmann, V.P.W. Böhm, C.P. Reisinger, J. Organomet. Chem. 1999, 576, 23; b) T. Weskamp, V. P. W. Böhm, W. A. Herrmann, J. Organomet. Chem. 2001, 585, 348; c) W. A. Herrmann, M. Elison, J. Fischer, C. Kocher, G. R. J. Artus, Angew. Chem. Int. Ed. Engl. 1995, 34, 2371; d) W. A. Herrmann, J. Fischer, K. Öfele, G. R. J. Artus, J. Organomet. Chem. 1997, 530, 259; e) J. Schwarz, V.P.W. Böhm, M. G. Gardiner, M. Grosche, W. A. Herrmann, W. Hieringer, G. Raudaschl-Sieber, Chem. Eur. J. 2000, 6, 1773.

[5] a) D. S. McGuinness, M. J. Green, K. J. Cavell, B. W. Skelton, A. H. White, J. Organomet. Chem. 1998, 565, 165; b) D. S. McGuinness, K. J. Cavell, B. W. Skelton, A. H. White, Organometallics 1999, 18, 1596; c) K. J. Cavell, D. S. McGuinness, Coord. Chem. Rev. 2004, 248,671 .

[6] a) M. S. Yoon, D. Ryu, J. Kim, K.H. Ahn, Organometallics 2006, 25, 2409; b) H. M. Lee, P.L. Chiu, C.-H. Hu, C.-L. Lai, Y.-C. Chou, J. Organomet. Chem. 2005, 690, 403; c) R. Wang, M. M. Piekarski, J. M. Shreeve, Org. Biomol. Chem. 2006, 4, 1878.

[7] a) G. P. Boldrini, D. Savola, E. Tagllavini, C. Trombini, A. Umanironchi, J. Organomet. Chem. 1986, 301, C62; b) S. A. Lebedev, V. S. Lopatina; E. S. Petrov, I. P. Beletskaya, J. Organomet. Chem. 1988, 344, 253; c) K.-C. Kong, C.-H. Cheng, Organometallics 1992, 11, 1972; d) S. Sustmann, P. Hopp, P. Holl, Tetrahedron Lett. 1989, 30, 689; e) T. Kelkar, T. Hanoaka, Y. Kubota, Y. Sugi, Catal. Lett. 1994, 29, 69; f) W. A. Herrmann, B. Cornils, Angew. Chem. Int. Ed. Engl. 1997, $36,1048$.

[8] B.-L. Lin, L. Liu, Y. Fu, S.-W. Luo, Q. Chen, Q.-X. Guo, Organometallics 2004, 23, 2114.

[9] M. C. Hartshorn, P. J. Steel, J. Aust. Chem. 1995, 48, 1587.

[10] C. M. Hartson, P. J. Steel, Chem. Commun. 1997, 541.

[11] K. Li, J. Darkwa, I. A. Guzei, S. F. Mapolie, J. Organomet. Chem. 2002, 660, 108.

[12] M. C. Hartshorn, P. J. Steel, Organometallics 1998, 17, 3487.

[13] I. A. Guzei, K. Li, G. A. Bikzhanova, J. Darkwa, S. F. Mapolie, Dalton Trans. 2003, 715.

[14] S. Mahapatra, R. N. Mukherjee, J. Chem. Soc., Dalton Trans. 1991, 2911.

[15] Z. Shirin, R. Mukherjee, J.F. Richardson, R. M. Buchanan, J. Chem. Soc., Dalton Trans. 1994, 465.

[16] S. O. Ojwach, I. A. Guzei, J. Darkwa, S. F. Mapolie, Polyhedron, in press.

[17] T. N. Sorrell, D. L. Jameson, J. Am. Chem. Soc. 1982, 104, 2053.

[18] F. H. Allen, Acta Crystallogr. 2002, B58, 380.

[19] S. K. Yen, L. L. Koh, F. E. Hahn, H. V. Huynh, T. S. A. Hor, Organometallics 2006, 25, 5112.

[20] J. De Vries, Dalton Trans. 2006, 421.

[21] S. M. Nelana, I. A. Guzei, J. Darkwa, unpublished results.

[22] D. Drew, J. R. Doyle, Inorg. Synth. 1972, 13, 47.

[23] E. Rule, I. M. Han, C. J. Elsevier, K. Vrieze, P. W. N. M. van Leeuwen, C.F. Roobeek, M. C. Zoutberg, Y. F. Wand, C. H. Stam, Inorg. Chim. Acta 1990, 169, 5.

[24] SADABS (version 2.05), SAINT (version 6.22), SHELXTL (version 6.10), SMART (version 5.622), Software Reference Manuals, Bruker AXS Inc., Madison, Wisconsin (USA) 2000-2003. 